UDC 78.071.1

DOI $10.33287 / 222019$

Medvednikova Tatiana, PhD in Arts, associated professor, heard of the chair "Piano», Dnipropetrovsk Academy Music after Mikhail Glinka tel. (095) 905 - 05 - 49 e-mail: t.medvednikova@meta.ua

Panchenko Vladislav, Graduate student of the chair «Piano» of Dnipropetrovsk Music Academy after Mikhail Glinka tel. (096) $818-21-25$ e-mail: dnepryanin1995@gmail.com https://orcid.org/0000-0002-0277-729X

\title{
THE DRAMATURGY OF THE SONATA CYCLE BY L. VAN BEETHOVEN (on the example Sonata № 3 C-dur op. 2)
}

The purpose of the article is to analyze and develop stylistic features of L. Beethoven's sonata cycle for a more accurate reproduction of the play's dramaturgy. The following research methods are used in the work the next. There are historical and cultural approach (research and analysis of works dedicated to L. Beethoven's creative heritage); method of comparative style analysis and general system-structural approach (comparing the problem of the era and its development); the traditional method of source studies as a historical discipline (the work is based on existing sources). Scientific novelty is to identify the peculiarities of creativity and specific performance of works by L. van Beethoven, from the point of view of the contemporary performer, characterizing the attitude of the composer to accurate performance, classification of means of expression and their use precisely when performing works on the piano. Conclusions. From the very beginning of the work on the sonatas, the pianist should pay attention to the stylistic features of the performance of Beethoven's sonatas. Taking a leading role in the study of the author's text, stylistics gives the work a unique sound, and the skill and the right approach maximize the performer of the playwright's reproduction of the play. Getting acquainted with Beethoven's sonatas requires a meticulous attitude to the applicative, dash dynamic notes and 
pedalisations written by the composer himself. The unity and interaction of the means of musical expression, such as: dynamics, fingering, pedaling and strokes, plays a special role in the performance of L. Beethoven's sonata cycle and brings the pianist closer to the most accurate transmission of the composer's creative intent. Condemning the carelessness of the execution of the author's instructions, Beethoven requires not only accurate, but above all expressive of their execution. Thus, the composer draws the artist's attention to their content.

The key words: performer, dramaturgy, pianist, means of musical expression, sonata, piano.

Медведнікова Тетяна Олександрівна, кандидат мистецтвознавства, доцент, завідувач кафедри «Фортепіано» Дніпропетровської академії музики ім. М. Глінки

Панченко Владислав Станіславович, магістрант кафедри «Фортепіано» Дніпропетровської академії музики ім. М. Глінки

Драматургія сонатного циклу Л. ван Бетховена (на прикладі Сонати № 3 C-dur op. 2)

Метою пропонованої статті $\epsilon$ аналіз стилістичних особливостей сонатного циклу Л. Бетховена для більш точного піаністичного відтворення драматургії твору. Матеріалом дослідження постає Соната № 3 C-dur op. 2. У роботі використано такі методи дослідження як історико-культурологічний підхід (вивчення та здійснення аналізу праць присвячених питанню творчої спадщини Л. Бетховена), метод порівняльного стильового аналізу, а також загальний системноструктурний підхід. Наукова новизна презентованої статті полягає у виявленні драматургічних особливостей та виконавської специфіки в інтерпретації фортепіанних творів Л. Бетховена; з точки зору сучасного виконавця-піаніста здійснено класифікацію засобів художньої виразності та окреслено їх використання саме при виконанні творів на фортепіано. Висновки. Від початку роботи над сонатами, піаністу слід звернути увагу на стилістичні особливості виконання сонат Л. Бетховена. Займаючи ведучу роль у вивченні авторського тексту, стилістика надає твору неповторного художньо-естетичного звучання, а майстерність та вірний інтерпретаційний підхід максимально наближують музиканта-виконавця до відтворення певної драматургії твору. Виконання сонат Л.Бетховена вимагає прискіпливого відношення до аплікатурних, штрихових, динамічних приміток та педалізації написаних композитором. Єдність та взаємодія засобів 
музичної виразності, таких як: динаміка, аплікатура, педалізація та штрихи, відіграють особливу роль у виконанні сонатного циклу Л. Бетховена та наближують музиканта-піаніста до найбільш точного відображення ідейно-образного творчого задуму композитора. Засуджуючи недбале відношення до виконання авторських вказівок, інтерпретація фортепіанних шедеврів Л. Бетховена вимагає не тільки точного, але й, насамперед, художньо-виразного, естетичнодовершеного їх виконання.

Ключові слова: виконавець, драматургія, піаніст, засоби музичної виразності, соната, фортепіано.

Медведникова Татьяна Александровна, кандидат искусствоведения, доцент кафедры «Фортепиано» Днепропетровской академии музыки им. М. Глинки

Панченко Владислав Станиславович, магистрант кафедры «Фортепиано» Днепропетровской академии музыки им. М. Глинки

Драматургия сонатного цикла Л. Бетховена (на примере Сонаты № 3 C-dur op. 2)

Целью статьи является анализ стилистических особенностей сонатного цикла Л. Бетховена для более точного пианистического воспроизведения драматургии произведения. Материалом исследования является Соната № 3 C-dur op. 2. В работе использованы следующие методы исследования, а именно - историко-культурологический подход (анализ работ, посвященных вопросу творческого наследия Л. Бетховена), метод сравнительного стилевого анализа, а также общий системно-структурный подход. Научная новизна заключается в выявлении драматургических особенностей и выявлении исполнительской специфики в интерпретации фортепианных произведений Л. Бетховена; с точки зрения современного исполнителяпианиста осуществлена классификация средств художественной выразительности и охарактеризовано их использование именно при исполнении произведений на фортепиано. Выводы. В начале работы над сонатами, пианисту следует обратить внимание на стилистические особенности исполнения сонат Л. Бетховена. Концентрируя ведущую роль в изучении авторского текста, стилистика придает произведению неповторимости звучания, а мастерство и правильный пианистический подход максимально приближают исполнителя к воспроизведению драматургии всего произведения. Исполнение сонат Л. Бетховена требует тщательного отношения к апликатурным, штриховым, 
динамическим примечаниям, а также педализации, написанных самим композитором. Единство и взаимодействие средств музыкальной выразительности, таких как динамика, аппликатура, педализация, штрихи, имеет особую роль в процессе исполнения сонатного цикла Л. Бетховена и, безусловно, приближает музыканта-пианиста к наиболее точному раскрытию творческого замысла выдающегося композитора. Осудительно небрежное отношение к воспроизведению авторских указаний в интерпретации фортепианных произведений, требует не только точного, но и прежде всего их художественновыразительного исполнения.

Ключевые слова: исполнитель, драматургия, пианист, соната, средства музыкальной выразительности, фортепиано.

Relevance of research problem. The study of the creative heritage of the ingenious composer, pianist and teacher Ludwig van Beethoven is an urgent task of contemporary art criticism, piano pedagogy and professional performance.

The Beethoven Piano Sonatas represent a great spiritual legacy of our time, make up a large part of the piano repertoire of world-class performers including Ukrainian performers, and play an important role in the educational process from pupils of music schools to students of Higher Educational Institutions. This determines the types and number of research sources devoted to various problems of composer piano sonatas.

Literature analysis. This article examines works based on a historical study of Beethoven's work, namely the textbook by N. Kashkadamova «The Art of Performing Music on Keyboard-String Instruments» [3], and the book «32 Beethoven's Sonatas» by O. Goldenweiser [2], which analyzes exanes the sonatas in terms of performance, and analyzes each Beethoven sonata. Outstanding L. Kirillina's monograph «Beethoven. Life and Creativity» in 2 volumes [4], which introduce the reader with the history of Beethoven's life, his environment which influenced on his creativity, with the people the composer interacted with. Renowned N. Golubovskaya's book «The Art of Pedalization» is carefully analyzed [1]. Particular professional attention is paid to K. Czerny's book «On the faithful performance of Beethoven's piano sonatas» [6].

The purpose of this scientific article is to analyze and develop stylistic features of L. Beethoven's sonata cycle for a more accurate reproduction of the play's dramaturgy. 
The subject of the article is the genre of piano sonata in the works of L. Beethoven. The object is the dramaturgy of the sonata cycle,

Presenting main material. Dramaturgy is a system of expressive means and techniques of embodiment of dramatic action in works of the musical-stage genre (opera, ballet, operetta). The basis of musical dramaturgy is the general laws of drama as a form of art: the presence of a pronounced central conflict, which is revealed in the struggle of forces of action and counteraction, a certain sequence of stages of the disclosure of a dramatic design (exposure, plot, development, culmination, decoupling). etc. which has a direct bearing on the problems of forming instrumental works.

The term «musical dramaturgy» is also used to refer to works of instrumental music that are unrelated to a stage act or a specific literary program. It is customary to say about symphonic dramaturgy, sonata form dramaturgy, etc. The inherent ability of music to portray images of matter of fact in motion, development, interlacing and combating contradictory beginnings (start) allows an analogy with dramatic action. Thus, the form of sonata allegro was and remains a universal example in terms of reflecting reality.

Well-known perfomer and amazingly celebrated teacher of the twentieth century E. Lieberman said: «We are used to the fact that Beethoven wrote thirty-two sonatas for piano. We are so used to it that we are not always aware - it is too much! Turning them over, you do not get tired of wondering the similarities of the sonatas to each other. Thirty-two different concepts, thirty-two musical plots, thirty-two interpretations of sonata allegro and cyclical sonata form. Using literary terminology, one can speak of thirty-two musical novels with their characters, their fates and conflicts» [5].

For today's pianists, the attention to mastering and the most accurate execution of stylistic features of the sonata cycle is an integral part of the work with the genre, as the performing vision of the dramaturgy of Beethoven's sonatas changes according to:

1) exact execution of the author's text;

2) understanding the historical consciousness of the classicism;

3) understanding the modern era, which imprints on the peculiarities of the performance of works of the past;

4) the emergence of new researchers of the composer's music and new studies of his work;

5) the appearance of modern pianism;

6) new types of concert practice; 
7) fudio and video recording;

8) development and evolution of instrument.

First of all, exactly in the piano sonata that the main features of the Beethoven style dramaturgy were formed - the characteristic thematicism, the manner of presentation of the musical text and the method of composition. For Beethoven, the Piano Sonata was a kind of creative laboratory where the most courageous ideas were tested and found in symphonies.

In order to embody his imaginative designs, the composer dramatically develops the orchestra, and sometimes completely rejects the classical ideals of sound (transparency and clarity) and comes to the symphonic interpretation of the piano. It is due to changes in the invoice, such as the expansion of the actual used piano range, the greater massiveness of presentation, the enrichment of the performing technique. Beethoven finds distinct sound colors in the extreme registers of the piano, which were little used by his predecessors. Own bass moves, in particular, the bass register, which previously had a very limited role as a harmonic basis.

The contrast of the sound of different texture registers becomes evident when comparing individual motives or distinct textured constructions. One of Beethoven's favorite techniques is the register sounds, which are repeatedly linked to the crossing of hands, which very much imitate the piano alternate performances of orchestral instruments. The composer used this textbook from early to late. For example, Sonata No. 3 II part vol. 13-18; vols. 59-61.

Other textured types are also possible, such as quartet four voices. For example Sonata No. 3 III part vols. 1-5.

Working on a piece of music creation, we must rely on objective and subjective means of musical expression as an important part of the structure of dramaturgy. Objective (author's) means of musical expression are: order, tone, size, melody, harmony, rhythmic and textual presentation, subjective (performing) means of musical expression are: tempo, dynamics, articulation, fingering, pedal, quality of intonation others.

Since objective means cannot be influenced by the performer, many revisions of Beethoven's sonatas are being built on the interpretation of subjective means of musical expression: Czerny, Schnabel, Weiner, Martinsen, Goldenweiser.

One element of the unveiling of the play's dramaturgy is the metrorhythmic precision of the performance, which cementes the form. Schnabel, for example, understands the system of metronomic designations to identify 
the dramaturgy of a work. Accurately recording the smallest changes in tempo on the edges of form sections. Schnabel did not require steady execution of his metronomic designations, but only wanted to give the performers an approximate scheme of tempo modifications as a model for developing their own interpretation plan.

Realizing the importance of unveiling the work of musical expressiveness such as dynamics, fingering, pedalisation, strokes, and tempo, Beethoven, beginning with the first piano sonatas, meticulously wrote down his requirements for the performance of music, and improved them over time. His remarks differ markedly different from the performance designations of his predecessors in detail and professional specificity.

Before Beethoven, the composers did not specify the dynamics in detail, mainly forte and piano, only occasionally ff and pp, or the standard crescendo or diminuendo dynamics.

A. Aronov gives examples of designation of the dynamic levels used by Beethoven in the record, they vary from 3 ppp to $3 \mathrm{fff}$ using all layers of dynamic gradation ( $p p p ;$ piu pp; pp; piu $p ; p ; m p ;$ mezza voce; sotto voce; $m f$; $f$; piu $f$; ff; fff). Its dynamics can be characterized as unexpected, sudden, as «dinamica subita». The most typical dynamic techniques for Beethoven were contrasting dynamic levels, accentuation and nuance $p<p$ (that is, a crescendo that breaks into a culminating point);

The composer also often put a crescendo on the descending passages and diminuendo on the descending ones. The objective justification for this was the peculiarities of harmony or rhythm in such a place. For example Sonata No. 3 I part of vols. 207-216.

Such attitude to the dynamic possibilities of the piano emphasizes the conflict of the dramaturgy of Beethoven's sonatas, including the 3rd.

Due to Beethoven's understanding of performance difficulties, as well as to achieve the result he needed, he often wrote in certain places fingerprinting, which greatly assisted the performer in choosing the performance of the place. The Beethoven application guidelines preserved in some of his sonatas testify that the composer made extensive use of all five fingers, giving particular weight to the work of the first finger. For example, Sonata No. 3 part IV vols. 269-272.

Also, the composer greatly contributed to the development of the art of pedaling, achieving completely new effects. As N. Golubovskaya writes in her article about Beethoven, «Beethoven's music is a turning point in the piano texture and thus pedaling. Starting with Haydn's purely letter-like 
manner, he boldly and boldly pushes the piano's frame, foreshadowing the era of romanticism» [1].

Beethoven is the first to start pedaling, but does so only in particularly contradictory cases. Often, the composer wrote a pedal that lasted almost until the beginning of the next harmony, passing everywhere on the clock lines or pedaling on sustained notes and setting a crescendo that made the performer listen unnoticed to the unprepared hearing of the vibrations of the strings.

Beethoven also used the left pedal, demanding its exact application. In places where it was designated to perform, Beethoven sought to impart melodies of sophisticated timbre.

It should be noted the variety of tempos that enhance the understanding of the sonata. Throughout his life, Beethoven tried to answer the question, «How to convey your sense of pace most accurately to performers?» The composer identifies four major tempos: Adagio, Andante, Allegro and Presto.

Andante in Beethoven retains classic interpretation as a «step» movement, although later in the nineteenth century the term would be interpreted as defining a slow pace. For Beethoven, the symbol of slow tempo is Adagio, and the speed range between Adagio and Presto is much broaer than Mozart.

Beethoven was convinced that it was difficult not only to record, but also to determine exactly one tempo, correct for all cases of performance of the work, because the perception of it is relative, depending on many circumstances, objective (strength and massiveness of sound, acoustics) and subjective ( temperament and mood of the listener, or even the time of day). That's why, most piano pieces were left without the author's metronome designation.

N. Fischman, on the basis of all preserved metronomic designations of the author, made the following plate (the basic rhythmic value is a quarter):

$$
\begin{aligned}
& \text { Adagio } 20-69 \\
& \text { Andante } 38-84 \\
& \text { Allegro } 88-348 \\
& \text { Presto } 184-396
\end{aligned}
$$

Despite the overlapping of the tempo, there is no contradiction in this plate, since the real rate of tempo depends on a number of characteristics, such as the units of account indicated in the clock size, the length of the 
phrases, the rhythms found in the ratio of the note values between themselves, or the heavy or light articulation.

Conclusions. Getting acquainted with Beethoven's sonatas requires a meticulous attitude to the applicative, dash dynamic notes and pedalisations written by the composer himself. The unity and interaction of the means of musical expression, such as: dynamics, fingering, pedaling and strokes, plays a special role in the performance of L. Beethoven's sonata cycle and brings the pianist closer to the most accurate transmission of the composer's creative intent. Condemning the carelessness of the execution of the author's instructions, Beethoven requires not only accurate, but above all expressive of their execution. Thus, the composer draws the artist's attention to their content.

Research prospects. Beethoven's sonatas hold a special place in the repertoire of the modern pianist. Attention to the exact reproduction of the dramatic design of the composer always remains a pressing issue of the performing arts as well as the subjective vision of the artist that before playing the music may be different from the original recording.

\section{Список використаних джерел і літератури:}

1. Голубовская Н. Искусство педализации. Москва : Музыка, 1974. 96 с.

2. Гольденвейзер А.Б. 32 сонаты Бетховена, Москва : Музгиз, 1955-1959. 288 с.

3. Кашкадамова Н. Мистецтво виконання музики на клавішно-струнних інструментах : Навч. посіб. Тернопіль : «АСТОН», 1998. 300 с.

4. Кирилина Л. Бетховен. Жизнь и творчество. Москва : Научно-издательский центр «Московская консерватория», 2009. $536 \mathrm{c.}$

5. Либерман Е. Фортепианные сонаты Бетховена. Москва : Музыка. 2006. 88 с.

6. Черни К. О верном исполнении всех фортепианных сочинений Бетховена. Санкт-Петербург : Лань, 2011. 120 с.

\section{References:}

1. Golubovskaja, N. (1974). The art of pedaling. Moskva: Muzyka [in Russian].

2. Gol'denvejzer, A.B. (1959). 32 Beethoven sonatas. Moskva: Muzgiz [in Russian].

3. Kashkadamova, N. (1998). The art of performing music on keyboard-string instruments. Ternopilj: «ASTON» [in Ukrainian].

4. Kirilina, L. (2009). Beethoven. Life and creation. Moskva: Nauchno-izdatel'skij centr «Moskovskaja konservatorija» [in Russian].

5. Liberman, E. (2006). Beethoven's Piano Sonatas. Moskva: Muzyka [in Russian].

6. Cherni, K. (2011). On the correct performance of all Beethoven's piano works. SanktPeterburg : Lan' [in Russian]. 